\title{
Container maritime transport on an international scale: a model to simulate the demand flow in the Mediterranean basin
}

\author{
F. Russo \& V. Assumma \\ Università degli Studi Mediterranea di Reggio Calabria \\ DIMET - Dipartimento di Informatica, Matematica, \\ Elettronica e Trasporti, Italy
}

\begin{abstract}
This paper presents a model to simulate the freight demand flow of containers on an international scale, considering as a reference area the Mediterranean basin.

The models specified and calibrated represent a development of models used in the literature and they are applied to assess the effects of modifications on the configuration of the national transport system. The modifications correspond to different exogenous scenarios, relative to national and international socioeconomic and demographic variables.

Some results emerge from the analysis of the calibrated models, in particular concerning the importance of the different maritime services for import and export.

Keywords: freight, international mobility, container.
\end{abstract}

\section{Introduction}

The objective of this paper is the development of models to simulate the freight demand flow in the Mediterranean basin exchanged by containers.

The models in literature are of interregional type or just crossborder [1], few papers treat transport models on an international level. In particular, there are no transport models involving industrialized countries and developing countries. A detailed classification of international freight transportation models is reported in [2].

This work is part of a two-year research project financed by the Italian Ministry of University and Research, whose general objective is to define guidelines for the 
competitiveness of the Italian transhipment ports of Gioia Tauro, Cagliari and Taranto in the euro-Mediterranean context. In the complete system of analysis the starting model is the one regarding the development, and the application to the Mediterranean area, of aggregate procedures [3] to estimate the demand variables of container maritime transport. The second is the model presented in this paper. The third is the model regarding the choice of maritime container services and ports [4]. Finally a specific paper [5] presents method to evaluate the efficiency of container transhipment ports that operate in the same region.

A general review on national transport models is reported in [6]. From the literature it emerges that only the agriculture aspect of trade is modeled in the Mediterranean area. In the context of studies conducted by the Femise Research Programme, the MEDINA AGRO I [7] aims to analyze the effects of the creation of the Euromediterranean Free Trade Zone in agriculture.

The determinants of the demand for general maritime import and export are analyzed only for one specific country: Spain [8]. General work related to different aspects of a single port in the Spanish and Mediterranean context have been studied in [9].

Specific aspects related to the use of the models in a design procedure are analyzed with emphasis on road network [10], similar evolution could be studied for maritime network.

In this paper is reported a short description of the study area, the Mediterranean basin (section 2), including demand and supply database. In section 3 is reported the current demand of freight exchanged in the Mediterranean basin and in section 4 are reported models and criteria used for their specification, calibration and validation. In section 5 are presented the calibrated coefficients. Some results that emerge from the analysis of the calibrated models are reported in section 6 .

\section{Study area and database}

To analyze the freight flow by container, in the Mediterranean basin, considering only the transport by ship, four zones have been defined: two zones inside Mediterranean basin and two zones outside Mediterranean basin.

The zones inside Mediterranean basin are:

- $\quad$ North-Med (North): Italy, France, Spain and Greece;

- South-Med (South): Morocco, Algeria, Tunisia, Malta, Libya, Egypt, Jordan, Israel, Lebanon, Syria, Turkey, Cyprus, Palestine.

North is composed of countries with strong similarities in terms of production capacity and manufacturing demands; South is composed of countries with low production capacity and manufacturing demands among the Mediterranean basin. In this context, Malta and Cyprus, while politically belonging to the North, were inserted in South for their production capacity and manufacturing demands.

The zones outside Mediterranean basin are:

- European Union excluded North (EU19): Austria, Belgium, Denmark, Estonia, Finland, Germany, Ireland, Latvia, Lithuania, Luxembourg, 
Netherlands, Poland, Portugal, United Kingdom, Czech Republic, Slovakia, Slovenia, Sweden, Hungary;

- World excluded EU19, South and North.

Data for models calibration were obtained from different sources:

- World Development Indicator (www.worldbank.org);

- Italian National Institute for Foreign Trade (www.ice.gov.it);

- Italian National Institute of Statistics (www.istat.it).

Some social-economic variables were obtained (year 2006) from the World Development Indicator [11]:

- $\quad$ Gross domestic product (US\$);

- $\quad$ Industry value added (US\$);

- $\quad$ Agriculture value added (US\$);

- Total population;

- Unemployment (\% of total labour force);

- Inflation (\%);

- $\quad$ Energy production (kg oil equivalents);

- $\quad$ Energy use (kg oil equivalents);

- $\quad$ Electricity production (kwh);

- $\quad$ Electric power consumption (kwh per capita).

National Institute for Foreign Trade [12] provided aggregate and disaggregate data (year 2006) regarding:

- value of freight (number of container) exchanged between the countries in our study area.

\section{Demand structure}

In order to reproduce the current demand of freight exchanged by sea in the Mediterranean basin in 2006 it is necessary to analyze the connections O/D. The current demand of freight exchanged was fully represented by 2006; given the difficulty to finding data for all the countries in our zones, the database could be updated and completed, and the work can move ahead. Today there is no single database with all the statistics of freight exchanged in the Mediterranean basin, and the existing data, elaborated from various sources, are often conflicting.

Although the current demand of freight exchanged in the Mediterranean basin was fully represented, it is not necessary to analyze all the connections in O/D matrix. The following sections report a description of simulated freight demand flows and not simulated freight demand flows.

\subsection{Simulated demand container flows}

In order to analyze freight demand flows exported in the Mediterranean basin (fig. 1), it is useful to define the following aggregated demand flows:

- freight exported from North to South;

- freight exported from North to World excluded EU19, South and North; 
- freight exported from South to North;

- freight exported from South to EU19;

- freight exported from South to World excluded EU19, South and North.

Similarly to analyze freight demand flows imported in the Mediterranean basin (fig. 1), it is useful to define the following aggregated demand flows:

- freight imported to South from EU19;

- freight imported to North from World excluded EU19, South and North;

- freight imported to South from World excluded EU19, South and North.

\begin{tabular}{|c|c|c|c|c|}
\hline O/D & North & South & EU19 & $\begin{array}{c}\text { World-EU19- } \\
\text { North } \\
\text { South }\end{array}$ \\
\hline North & & & \\
\hline South & & & \\
\hline $\begin{array}{c}\text { World-EU19- } \\
\text { North } \\
\text { South }\end{array}$ & & & \\
\hline
\end{tabular}

Figure 1: $\quad \mathrm{O} / \mathrm{D}$ matrix.

\subsection{Not simulated demand container flows}

Some connections in O/D matrix are not simulated (oblique line in fig. 1) because there are only little amounts of freight exchanged by sea respect to land:

- amounts of freight exported from North to North;

- amounts of freight exported from South to South.

The amounts of freight exported by sea from North to North had an increased by means of European policies that support the start-up of services by motorway of the sea like Marco Polo. But this effect is more prevalent in the years after 2006 , which is the base year for the simulation.

Some O/D connections are not simulated (cross line in fig. 1) because freight is almost exclusively exchanged by land:

- freight imported to North from EU19;

- freight exported from North to EU19.

Some O/D connections are not simulated (white box in fig. 1) because it is assumed that no ports of Mediterranean basin are used:

- $\quad$ freight exported from EU19 to EU19; 
- freight exported from EU19 to World excluded EU19, South and North;

- freight exported from World excluded EU19, South and North to EU19.

One connection, in O/D matrix, is not simulated (grating in fig. 1) because the choice of a port hub in Mediterranean basin depends only by business strategies of major carriers and not by economic conditions of countries (work in progress on these themes):

- freight exported from World excluded EU19, South and North to World excluded EU19, South and North.

Fig. 1 reports the O/D matrix of the freight demand flows exchanged by sea and that have at least one extreme in a port of the Mediterranean basin.

\section{Specification of models}

Two specifications of demand model O/D are proposed:

- $\quad$ exportation model;

- importation model.

The exportation (importation) model estimates the amount of freight exported (imported) from a country.

It is used the regression model by category, that is a specification of the descriptive models.

The model is specified and calibrated for all the connection (black) in O/D matrix in fig. 1 . The model, in its higher disaggregated form, can be written as:

$$
y_{i j}=\sum_{w} \beta_{w} \cdot x_{j w}+\sum_{k} \beta_{k} \cdot x_{i k}+z
$$

where, considering as an example the amounts of container freight exported from North to South:

- $\quad \mathrm{i}$ is a country of North that exports toward country $\mathrm{j}$ of South a number of container $\mathrm{y}_{\mathrm{ij}}$;

- $\mathrm{x}_{\mathrm{ik}}$ is the generic attribute $\mathrm{k}$ of country $\mathrm{i}$;

- $\mathrm{x}_{\mathrm{jw}}$ is the generic attribute $\mathrm{w}$ of country $\mathrm{j}$;

- $\quad \beta_{\mathrm{w}}$ and $\beta_{\mathrm{k}}$ are model coefficients to be estimated;

- $\quad \mathrm{z}$ is a random variable that represents the error.

Given the difficulty finding disaggregated data (attributes) for all the countries in the zones and container flows on all the connections in O/D matrix, it is necessary to specify the model (1) in other way. We do not consider, as observed value, the single $\mathrm{y}_{\mathrm{ij}}$ country to country container flows, but the value:

$$
Y_{i J}=\sum_{j \in J} y_{i j}
$$

In the case of container freight exported from North to South, previously exemplificated, we have: 
814 Sustainable Development and Planning V

$$
Y_{i \text { South }}=\sum_{j \in \text { South }} y_{i j}
$$

If we consider the models (1) and (2), $\beta_{\mathrm{w}} \mathrm{X}_{\mathrm{JW}}$ has a constant value for all the $\mathrm{Y}_{\mathrm{iJ}}$ and must be ignored in the calibration.

For the first two rows in O/D matrix in fig. 1 the model is:

$$
Y_{i J}=\sum_{k} \beta_{k} \cdot x_{i k}+z
$$

Let us suppose in a compact way that $\beta \cdot X_{i}=\sum_{k} \beta_{k} \cdot x_{i k}$ the model well be write as:

$$
Y_{i J}=\beta \cdot X_{i}+z
$$

where:

- $\quad \mathrm{Y}_{\mathrm{iJ}}=$ dependent or explicative variable; in our case it is the export of freight, in container, from a country i toward an aggregate region of country $\mathrm{J}$;

- $\mathrm{X}_{\mathrm{i}}=$ independent or explicative variable in a vector form; in our case they are the social-economic variables for the country $i$;

- $\beta=$ coefficients vector to be estimated; the method used, least squares, means that the overall solution minimizes the sum of the squares of the errors made in solving every single equation;

- $\mathrm{i}=1, \ldots, \mathrm{n} \quad$ with $\mathrm{n}=$ total number of observations (countries);

- $\mathrm{J}=$ considered zone or aggregate region of country.

Similarly to analyze demand of freight imported in the Mediterranean basin, if we consider (1) and (2) the model is:

$$
Y_{I j}=\sum_{i \in I} y_{i j}
$$

The model calibrated is:

$$
Y_{I j}=\sum_{w} \beta_{w} \cdot x_{j w}+z
$$

that is:

$$
Y_{I j}=\beta \cdot X_{j}+z
$$

For the third and fourth rows in O/D matrix in fig. 1 the model is the (4). 


\section{Calibrations}

Several model specifications were carried out, with progressive additions of different sets of social-economic attributes.

It is possible to identify two main types of specification and calibration. The first type is operational (OP), because attributes are generally available in the literature, allowing us to recalibrate the model for subsequent years. These attributes usually are the basis of the programs of the various countries (finance laws) because are the foundations for the forecast of Central Banks. The second type is explanatory (ES) because attributes have not a simple availability in the literature, but they explain the complexity of the model.

The OP type of models has the following attributes.

- Gross Domestic Product, GDP (US\$): it is the sum of gross value added by all resident producers in the economy plus any product taxes and minus any subsidies not included in the value of the products. It is calculated without making deductions for depreciation of fabricated assets or for depletion and degradation of natural resources. Data are in current U.S. dollars. Dollar figures for GDP are converted from domestic currencies using single year official exchange rates.

- Industry Value Added, IVA (US\$): it comprises value added in mining, manufacturing (also reported as a separate subgroup), construction, electricity, water, and gas. Value added is the net output of a sector after adding up all outputs and subtracting intermediate inputs. It is calculated without making deductions for depreciation of fabricated assets or depletion and degradation of natural resources.

- Agriculture Value Added, AVA (US\$): it includes forestry, hunting, and fishing, as well as cultivation of crops and livestock production. Value added is the net output of a sector after adding up all outputs and subtracting intermediate inputs. It is calculated without making deductions for depreciation of fabricated assets or depletion and degradation of natural resources.

- Total Population, TP: it is based on the de facto definition of population, which counts all residents regardless of legal status or citizenship - except for refugees not permanently settled in the country of asylum, who are generally considered part of the population of their country of origin. The values shown are midyear estimates.

The ES type of models has the following attributes.

- Energy Production, EnP ( $\mathrm{kg}$ oil equivalents): it refers to forms of primary energy--petroleum (crude oil, natural gas liquids, and oil from nonconventional sources), natural gas, solid fuels (coal, lignite, and other derived fuels), and combustible renewables and waste--and primary electricity, all converted into oil equivalents.

- Energy Use, EnU (kg oil equivalents): it refers to use of primary energy before transformation to other end-use fuels, which is equal to indigenous production plus imports and stock changes, minus exports 
and fuels supplied to ships and aircraft engaged in international transport.

- Electricity Production, ElP (kwh): it is measured at the terminals of all alternator sets in a station. In addition to hydropower, coal, oil, gas, and nuclear power generation, it covers generation by geothermal, solar, wind, and tide and wave energy, as well as that from combustible renewables and waste. Production includes the output of electricity plants that are designed to produce electricity only as well as that of combined heat and power plants.

- Electric Power Consumption, EIPC (kwh per capita): it measures the production of power plants and combined heat and power plants less transmission, distribution, and transformation losses and own use by heat and power plants.

For example to analyze amounts of freight container exported from North to South it is used the model (3) in the simpler form with just one attribute:

$$
Y_{i J}=\sum_{j \in \text { South }} y_{i j}=\beta \cdot G D P_{\mathrm{i}}
$$

where:

- $\mathrm{y}_{\mathrm{ij}}=$ export of freight, in container, from country $\mathrm{i}$ of North toward country $\mathrm{j}$ of South;

- $\mathrm{Y}_{\mathrm{iJ}}=$ export of freight, in container, from country i of North toward all the country $\mathrm{j}$ of South;

- $\mathrm{GDP}_{\mathrm{i}}=$ Gross Domestic Product (US\$) of country i;

- $\beta=$ model coefficient to be estimated;

- $\quad \mathrm{i}=1, \ldots$, North $\quad$ where North $=$ country of North;

- $j=1, \ldots$,South where South $=$ country of South.

In tab. 1 are the coefficients $\beta$ of the operational model specified with only variable Gross Domestic Product for exportation model from North to South and exportation model from South to North, and coefficients $\beta_{\mathrm{w}}$ of an explicative model.

\section{Preliminary conclusions}

Some results emerge from the analysis of the calibrated models. In particular in operational exportation model the coefficient of variable Gross Domestic Product is four times greater for Southern countries than for Northern countries; but the same coefficient are only a few times greater in explanatory exportation model.

The current demand of fright exchanged in the Mediterranean basin was fully represented, making particular reference to the Euromediterranean Free Trade Zone and to trade with the rest of the world. Given the difficulty finding data for all the countries in our study area, the database could be updated and completed. Today there is no single database with all the statistics of freight exchanged in 
the Mediterranean basin, and the existing data, elaborated from various sources, are often conflicting.

Table 1: Exportation model from North to South and from South to North.

\begin{tabular}{c|c|cccc}
\hline & & \multicolumn{2}{|c|}{ North to South } & \multicolumn{2}{c}{ South to North } \\
\hline Attribute & Unit & OP & ES & OP & ES \\
\hline GDP. & US\$*10 & 0,2945 & 0,9115 & 1,1454 & 1,0708 \\
$t$-student & & 2,46 & 8,06 & 4,73 & 4,10 \\
AVA. & US\$*10 & & $-3,26 * 10^{-8}$ & & \\
$t$-student & & & $-12,92$ & & 0,5117 \\
EnP & Kgoe & & $-7,4633$ & \\
$t$-student & & & $-13,26$ & \\
EnU & Kgoe & & $-3,7670$ & \\
$t$-student & & & $-3,19$ & \\
ElPC. & Kwh p.c. & & 46,1577 & & 0,6922 \\
$t$-student & & & 83,20 & & \\
\hline Rho & & 0,6697 & 1 & 0,6705 & \\
\hline
\end{tabular}

\section{References}

[1] Regan A. C. \& Garrido P. A. (ed.) Modeling Freight Demand and Shipper Behaviour: State of the Art, Future Directions. Preprint IATBR, Sydney, Australia, 2000.

[2] Russo F., Assumma V., Chilà G. \& Iannò, D., Stato dell'arte su modelli per la previsione dei flussi di domanda merci nei porti container hub. in Russo F. (ed.) I porti container italiani nel sistema euro-mediterraneo. Franco Angeli, Milano, 2010, ISBN 978-88-568-2482-7.

[3] Russo F. \& Musolino G. Container maritime transport at international scale: a procedure for aggregate estimation of demand variables. Proc. of Sustainable Development and Planning V. Brebbia C. A. (ed.), WIT Press, Southampton, Boston, 2011. ISBN 978-1-84564-544-1.

[4] Russo F., Chilà G. \& Iannò D. Container maritime transport at international scale: a model choice of service and hub port. Proc. of Sustainable Development and Planning $V$. Brebbia C. A. (ed.), WIT Press, Southampton, Boston, 2011. ISBN 978-1-84564-544-1.

[5] Russo F. \& Rindone C. Container maritime transport at international scale: Data Envelopment Analysis for transhipment ports. Proc. of Sustainable Development and Planning $V$. Brebbia C. A. (ed.), WIT Press, Southampton, Boston, 2011. ISBN 978-1-84564-544-1.

[6] Lundquist L. \& Mattsson L.G. National transport models: recent developments and prospects. Springer, 2001

[7] Lorca Corrons A. L'impact de la libéralization commerciale EuropeMéditeranéenne dans les échanges agricoles. Femise Research Programme, Paris, 2000

[8] Coto-Millàn P., Banos-Pino J. \& Villaverde Castro J. Determinants of the demand for maritime imports and exports. Transp. Res., vol. 41/E, 2005, pp. 357-372 
818 Sustainable Development and Planning V

[9] Coronado D., Acosta M., del Mar Cerban M. \& del Pilar Lòpez M. (eds.) Economic Impact of the Container Traffic at the Port of Algeciras Bay. Springer-Verlag, Berlin, 2006.

[10] Russo F. \& Vitetta, A. A topological method to choose optimal solutions after solving the multi-criteria urban road network design problem. Transportation, Volume 33, Issue 4, July 2006, Pages 347-370.

[11] World Bank Group, World Development Indicators, 2006.

[12] ICE, www.ice.it, National Italian Institute for Foreign Trade, 2006. 